\title{
Anoxia stress and effect on flesh quality and gene expression of tilapia
}

\author{
Jovana Silva Garbelini ZUANAZZI ${ }^{1 \star}$, Jorge Antonio Ferreira de LARA², Elenice Souza dos Reis GOES ${ }^{3}$, \\ Fernanda Losi Alves de ALMEIDA ${ }^{4}$, Carlos Antonio Lopes de OLIVEIRA ${ }^{5}$, Ricardo Pereira RIBEIRO ${ }^{5}$
}

\begin{abstract}
We evaluated the effect of the length of stay out of water on stress, gene expression, $\mathrm{pH}$ variation, blood parameters, histological analysis and water holding capacity (WHC) in fillets of the Nile tilapia (Oreochromis niloticus) cultivated in net-tanks. For this purpose, the fishes were maintained out of water under different periods of anoxia. Three and 6 min of anoxia in the pre-slaughter period increased the blood levels and mRNA expression of heat shock protein 70 the Nile tilapia and produced fillets with a less firm texture (greater sarcomere length). The evaluated periods of anoxia did not markedly affect $\mathrm{pH}$ and WHC. These results demonstrate that a pre-slaughter period of acute stress of up to 6 min does not considerably affect the quality of meat. The fillets of fish slaughtered in the early evening had a higher WHC and lower plasma glucose level than those slaughtered at the other time periods (morning and afternoon).
\end{abstract}

Keywords: HSP70; Oreochromis niloticus; pH; sarcomere length; water holding capacity.

Practical Application: Fish slaughter in the early evening produced fillets with greater WHC and lower plasma glucose.

\section{Introduction}

Stress has a negative effect on several aspects of animal production, including growth performance, resistance to diseases and meat quality (Iwama et al., 2004). One of the stress factors in fish farming before slaughter is the period when fishes are kept out of water. Davis \& Schreck (1997) and Martins et al. (2004) simulated this common form of stress in fish farms.

Inadequate slaughter methods can anticipate or delay the resolution of rigor mortis, depending on the level of stress of fish. Methods that cause severe stress cause lactic acid production, decrease in muscle $\mathrm{pH}$, loss in water holding capacity (WHC), protein denaturation, lipid oxidation and increase in microbial flora (Tornberg et al., 2000).

The WHC affects the appearance of meat before and during cooking and the palatability of fillets and is dependent on several factors, including $\mathrm{pH}$, ionic strength and osmotic pressure (Viegas et al., 2012). Water is one of the most abundant components in fish meat, is responsible for meat juiciness and softness and can directly affect the final yield and sensorial perception (Cheng \& Sun, 2008).

An important gene involved in environmental stress in fish encodes heat shock protein 70 (HSP70) (Wu et al., 2008). HSP70s are highly conserved in almost all organisms and play a major role in cellular defence (Fabbri et al., 2008; Morris et al.,
2013) by preventing the denaturation of other proteins under physiological stress.

Ryanodine receptors (RyRs) are large protein complexes responsible for controlling the release of calcium $\left(\mathrm{Ca}^{2+}\right)$ from intracellular stores (Darbandi \& Franck, 2009). The isoforms RyR1 and RyR3 have been characterised in the skeletal muscle of fish, particularly the Nile tilapia (Goes et al., 2015). Goes et al. (2015) demonstrated a correlation between the gene expression of these two isoforms, pre-slaughter stress and WHC in fillets of the Nile tilapia.

The WHC in animals under extreme stress decreases and causes water loss in fillets and significant economic losses in the fish industry. The objective of this study was to evaluate the effect of the length of stay out of water on stress, gene expression, $\mathrm{pH}$ variation, blood parameters, histological analysis and WHC in fillets of the Nile tilapia (Oreochromis niloticus) cultivated in net-tanks.

\section{Materials and methods}

The study complied with the guidelines of the Brazilian School of Animal Experimentation (COBEA) and was approved by the Ethics Committee on Animal Use of the State University of Maringá, Maringá, Paraná state (PR), Brazil. 


\subsection{Animals}

Fishes were cultivated in net-tanks located in Rio do Corvo in the city of Diamante do Norte, PR (22 39 'S; $\left.052^{\circ} 46^{\prime} \mathrm{W}\right)$. Animals with a mean weight of $69.75 \pm 9.92 \mathrm{~g}$ were grown at a rearing facility at a mean density of 117 fishes $/ \mathrm{m}^{3}$ in a screened tank with a steel structure, PVC-coated galvanised wire screen of mesh size of 0.75 inches, floats appropriate for net-tanks, circular feeders and a PVC lid.

During the growth period, fishes were fed three times a day with commercial food containing $32 \%$ of gross protein and $3,500 \mathrm{Kcal} / \mathrm{kg}$ of digestible energy. Seventy-two animals were slaughtered (mean weight of $835 \pm 85 \mathrm{~g}$ and total length of $36.64 \pm 0.96 \mathrm{~cm}$ ) from the sixth generation of the genetic improvement program of the Nile tilapia lineage GIFT of UEM. Fishes were made to fast for $24 \mathrm{~h}$ before the start of the experiment to empty their digestive tract.

\subsection{Experimental design}

Fishes were kept out of water under anoxia for different periods; these included 0 min (slaughtered immediately after being taken out of the tank) and 3 and 6 min of anoxia to simulate acute ante-mortem stress, which are common in fish farming. This method followed the recommendations of Davis \& Schreck (1997), Martins et al. (2004) and Castro et al. (2017).

In total, 72 fishes were captured, 24 for each proposed treatment. Analyses were conducted in eight batches, and each batch contained three fishes from each treatment. The experiments were conducted in the morning, afternoon and early evenings. This experimental design allowed the measurement of the decrease in $\mathrm{pH}$ over time after slaughter. All fishes were slaughtered on the same day by a blow to the head followed by decapitation and immediate perforation of the cranium. The fillets were manually prepared. The mean environmental temperatures were provided by the Meteorological System of Paraná (Simepar) and were $12.00 \pm 1.08^{\circ} \mathrm{C}$ in the morning, $20.00{ }^{\circ} \mathrm{C} \pm 4.74{ }^{\circ} \mathrm{C}$ in the afternoon and $24.00{ }^{\circ} \mathrm{C} \pm 1.55^{\circ} \mathrm{C}$ in the early evening.

\subsection{Blood parameters}

Two millimetres of blood was collected from each fish $(\mathrm{N}=72)$ by making a puncture in the tail vein using disposable syringes. The samples were placed in a water bath at $37^{\circ} \mathrm{C}$ for $10 \mathrm{~min}$ and centrifuged at 10,000 rpm for $10 \mathrm{~min}$, and the supernatant (serum) was collected. The samples were frozen at $-20{ }^{\circ} \mathrm{C}$ for cortisol and glycaemic analyses. The total cortisol level in the serum was determined by chemiluminescent microparticle immunoassay using Architect ci8200 (Abbott Laboratories, Diagnostics Division, Abbott Park, Illinois, USA) and reagent kits from the same manufacturer. Glycaemic levels were measured by the GOD-PAP method.

\section{4 pH curve and WHC}

As indicators of the quality of fillets, the $\mathrm{pH}$ curve and WHC were measured. The potentiometer used in this study (Sentron, Model 1001, Sentron Technologies, Roden, The Netherlands) contained electrodes specific for the $\mathrm{pH}$ measurement of meat products. The $\mathrm{pH}$ was measured at three different points (dorsal, central and ventral parts) of each fillet, in all 72 fillets, at $0,1,2,3,4$ and $24 \mathrm{~h}$ post mortem. Fillets were kept refrigerated during the measurements and were frozen after this period.

Fillets were unfrozen and weighted in an analytical scale (Shimadzu ATX224, Shimadzu Corporation, Kyoto, Japan), and aliquots were obtained from each fillet for WHC analysis. The analysis was conducted in triplicate, and each sample contained $1 \mathrm{~g}$ of fillet in natura. Each sample was placed in $1.5-\mathrm{mL}$ test tubes covered with Whatman ${ }^{\text {тм }}$ filter paper with a circumference of $55 \mathrm{~mm}$ and was centrifuged at 1,500 rpm for $4 \mathrm{~min}$ at $4^{\circ} \mathrm{C}$ in a centrifuge (Eppendorf, Model 5417R, Eppendorf North America, New York, USA).

After centrifugation, the samples were weighed and placed in a Fanem greenhouse (Model Orion 515, Fanem, São Paulo, Brazil) at $70^{\circ} \mathrm{C}$ for $12 \mathrm{~h}$. The dry samples were weighed once more and the Equation 1 below was used to calculate WHC:

$\mathrm{WHC}=\frac{(\mathrm{WSAC}-\mathrm{WDS})}{\text { WIS }} \times 100$

where WIS is weight of the initial sample, WSAC is the weight of the sample after centrifugation and WDS is the weight of the dry sample.

\subsection{Determination of the centesimal composition}

The percentages of lipids, humidity and ashes were determined according to the MAPA methodology (Brasil, 1981), and the total protein content was determined using Kjeldahl's method (Association of Official Analytical Chemists, 1995). All samples were analysed in triplicate.

\subsection{Gene expression}

Two grams of white muscle was collected from six fishes of each treatment and stored in RNAlater (Invitrogen, Carlsbad CA, USA) at $-20^{\circ} \mathrm{C}$ until the analyses. Total RNA was extracted with Trizol $^{\circledR}$ (Invitrogen, Carlsbad CA, USA) as per manufacturer's recommendations. All materials used were previously treated with RNase AWAY $^{\circledR}$ (Invitrogen).

The total RNA concentration was measured using a PICODROP ${ }^{\circledR}$ spectrophotometer (Picodrop Limited, Hinxton, United Kingdom). RNA samples were subjected to gel electrophoresis using a $1 \%$ agarose gel stained with a SYBR Safe ${ }^{\mathrm{Tm}}$ DNA gel stain (Invitrogen), and RNA integrity was visualised under a UV transilluminator L-Pix EX Image equipment (Loccus Biotecnologia, 330 José de Andrade, Cotia, SP 06714-200 Brasil). RNA samples were treated with DNase I (Invitrogen) to remove all genomic DNA residues as per the manufacturer's recommendations. 
cDNA was synthesised using Superscript TM III First-Strand Synthesis SuperMix (Invitrogen) according to the manufacturer's recommendations. Samples were kept at $-20^{\circ} \mathrm{C}$ until use.

The mRNA expression of ryanodine type 1 receptor (RyR1, XM_005474818.1), ryanodine type 3 receptor (RyR3, XM_005453445) and HSP70 (FJ213839.1) of O. niloticus was quantified by real-time reverse transcriptase PCR (qRT-PCR) using primers designed by Goes et al. (2015) For the endogenous control, the $\beta$-actin gene (XM_003455949) primer designed by Yang et al. (2013) was used.

qRT-PCR was conducted in the StepOne Plus Real-Time PCR system (Applied Biosystems, USA) using the fluorescent probe SYBR ${ }^{\circledR}$ Green PCR master mix (Applied Biosystems) as per the manufacturer's recommendations.

The designed primers proved to be adequate for the qRT-PCR analysis. The amplification efficiency of the genes of interest was similar and varied between $90 \%$ and $110 \%$. The analysis of dissociation curves did not reveal the presence of non-specific products or formation of dimers of primers, demonstrating the reliability of the mRNA expression data of the studied genes. The statistical analysis of the $\beta$-actin gene indicated no significant differences among the treatments, demonstrating the efficiency of using this gene as an endogenous control.

qRT-PCR data were transformed by calculating the adjusted cycle threshold $\left(\mathrm{C}_{\mathrm{t}}\right)$ as suggested by Coble et al. (2011):

Adjusted $\mathrm{Ct}=40-\left[\left(\right.\right.$ mean $\mathrm{C}_{\mathrm{t}}$ of the target gene $)+$ (median $\mathrm{C}_{\mathrm{t}}$ of the endogenous gene - mean $\mathrm{C}_{\mathrm{t}}$ of the endogenous gene $) \times($ slope of the target gene/slope of the endogenous gene $)]$.

\subsection{Histological analysis}

Samples of white dorsal muscle were dissected and fixed in 10\% neutral buffered formalin for $24 \mathrm{~h}$. Then, the samples were dried in increasing concentrations of alcohol (70\%, 80\%, $90 \%$ and $100 \%)$, diaphanised in xylol and embedded in paraffin. Longitudinal histological semi-serial sections with a $5 \mu \mathrm{m}$ thickness were obtained using a microtome and stained with haematoxylin and eosin to highlight the transversal bands of muscle fibres, as described by Behmer et al. (1976).

Histological slides were analysed under an optical microscope and photographed using a 100× objective lens in immersion oil. The mean length of the sarcomeres $(\mu \mathrm{m})$ from each animal was obtained by measuring the length $(\mu \mathrm{m})$ from 10 consecutive sarcomeres of 10 different myofibrils randomly chosen, as detailed by Sloss \& Kemp (1978). Image Pro-Plus version 4.5 was used for these measurements.

\subsection{Statistical analysis}

The effect of pre-slaughter treatments, time of slaughter of animals (morning, afternoon and early evening) and the relationship of the slaughter treatment period on WHC, $\mathrm{pH}$, glucose and cortisol and the gene expression of RyR1, RyR3 and HSP70 were tested. The effect of the period after slaughter on $\mathrm{pH}$ and sarcomere length was also evaluated.
The regression equations of $\mathrm{pH}$ were estimated as a function of the period of slaughter. The effect of treatment, time and period of slaughter and relationship of the slaughter treatment period and time of slaughter treatment were evaluated. Orthogonal contrast at $0,1,2,3$ and $4 \mathrm{~h}$ was tested together against the period of $24 \mathrm{~h}$ after slaughter.

RyR1, RyR3, HSP70, WHC, glucose, cortisol and $\mathrm{pH}$ were analysed using PROC MIXED of Statistical Analysis System (SAS, SAS Institute Inc. Cary, NC, USA), considering time-repeated measures only for $\mathrm{pH}$. The mean levels of these variables were compared among the pre-slaughter treatments using Tukey's test $(\mathrm{p}<0.10)$.

\section{Results}

\subsection{Blood cortisol and glucose}

The pre-slaughter periods of anoxia significantly affected $(\mathrm{P}<0.05)$ the serum cortisol levels, and the lowest mean level was observed at $0 \mathrm{~min}(12.31 \mu \mathrm{g} / \mathrm{dL})$ than at 3 and $6 \mathrm{~min}$ $(28.43 \mathrm{mg} / \mathrm{dL}$ and $25.13 \mu \mathrm{g} / \mathrm{dL}$, respectively) (Table 1$)$. The time of the day did not influence $(\mathrm{p}>0.05)$ the serum cortisol levels. Similarly, there was also no relationship $(p>0.05)$ between the period of anoxia and the time of the day in terms of cortisol levels.

The mean plasma glucose levels at $6 \mathrm{~min}(91.43 \mathrm{mg} / \mathrm{dL})$ were significantly higher $(\mathrm{p}<0.05)$ than those at 0 and $3 \mathrm{~min}$ (Table 1$)$. In addition, the period of the day significantly affected $(\mathrm{p}<0.05)$ the glucose level, and the highest level $(87.98 \mathrm{mg} / \mathrm{dL}$ ) was found in the morning. The plasma glucose levels did not change during the other periods (late afternoon and early evening).

\section{2 pH, WHC and centesimal composition}

The $\mathrm{pH}$ and WHC of tilapia fillets were not affected $(\mathrm{p}>0.05)$ by the different periods of anoxia before slaughter (Table 2 ). Moreover, there was no significant relationship $(\mathrm{p}>0.05)$ between the periods of anoxia and the time of the day for $\mathrm{WHC}$ and $\mathrm{pH}$. However, the assessment of fillets at the different times of the day indicated that the WHC was significantly lower $(\mathrm{P}<0.05)$ in the morning than in the early evening. The $\mathrm{pH}$ of fillets was not affected $(\mathrm{P}>0.05)$ by the time of slaughter.

Table 1. Mean \pm standard error of serum cortisol and glucose levels of Nile tilapias subjected to different periods of anoxia and slaughtered at different times of the day.

\begin{tabular}{|c|c|c|c|}
\hline & & \multicolumn{2}{|c|}{ Blood parameters } \\
\hline & & Cortisol $(\mu \mathrm{g} / \mathrm{dL})$ & Glucose (mg/dL) \\
\hline \multirow{3}{*}{ Period of anoxia (min) } & 0 & $12.31 \pm 4.01^{\mathrm{B}}$ & $61.28 \pm 4.18^{\mathrm{B}}$ \\
\hline & 3 & $28.43 \pm 3.71^{\mathrm{A}}$ & $71.96 \pm 4.08^{\mathrm{B}}$ \\
\hline & 6 & $25.13 \pm 3.71^{\mathrm{A}}$ & $91.43 \pm 4.40^{\mathrm{A}}$ \\
\hline Morning $\left(12^{\circ} \mathrm{C}\right)$ & & $23.65 \pm 3.44^{\mathrm{NS}}$ & $87.98 \pm 3.89^{\mathrm{A}}$ \\
\hline Time Afternoon $\left(20^{\circ} \mathrm{C}\right)$ & & $23.31 \pm 3.44^{\mathrm{NS}}$ & $72.55 \pm 3.87^{\mathrm{B}}$ \\
\hline Early evening $\left(24^{\circ} \mathrm{C}\right)$ & & $18.90 \pm 4.46^{\mathrm{NS}}$ & $64.13 \pm 4.84^{\mathrm{B}}$ \\
\hline
\end{tabular}

$\mathrm{NS}=$ not significant; means followed by different letters in the same column indicate significant differences by Tukey's test $(\mathrm{p}<0.05)$. 
The analysis of $\mathrm{pH}$ decrease (Table 2 ) indicated differences $(\mathrm{p}<0.05)$ in the mean $\mathrm{pH}$ values at $0,1,2,3$ and $4 \mathrm{~h}$ compared to at $24 \mathrm{~h}$ after slaughter. For the $\mathrm{pH}$ at $0-4 \mathrm{~h}$, a significant tendency to decrease $(\mathrm{p}<0.05)$ was estimated according to the equation $\mathrm{pH}=6.5598-0.04805 \mathrm{~h}\left(\mathrm{R}^{2}=0.993\right)$.

The analysis of the centesimal composition of fillets indicated that moisture, protein, ash and lipid contents did not differ ( $p>0.05$ ) between the pre-slaughter periods of anoxia and between the periods of slaughter. The ranges in the content of moisture, protein, ash and lipids were 75.71-75.80\%, 15.11-15.87\%, $4.10-4.20 \%$ and $3.35-3.70 \%$, respectively.

\subsection{Sarcomere length}

The different periods of anoxia significantly affected sarcomere length $(\mathrm{p}<0.05)$ (Table 3$)$, and the length was shortest with control treatment $(0 \mathrm{~min})$ than at the other periods. However, the different times of the day did not affect

Table 2. Mean \pm standard error of water holding capacity and $\mathrm{pH}$ of Nile tilapias subjected to different periods of anoxia and slaughtered at different times of the day.

\begin{tabular}{|c|c|c|c|c|}
\hline & & \multicolumn{2}{|c|}{ WHC (\%) } & $\mathrm{pH}$ \\
\hline \multirow{3}{*}{$\begin{array}{l}\text { Period of } \\
\text { anoxia (min) }\end{array}$} & 0 & \multicolumn{2}{|c|}{$56.91 \pm 0.22^{\mathrm{NS}}$} & $6.44 \pm 0.02^{\mathrm{NS}}$ \\
\hline & 3 & \multicolumn{2}{|c|}{$56.86 \pm 0.22^{\mathrm{NS}}$} & $6.44 \pm 0.02^{\mathrm{NS}}$ \\
\hline & 6 & \multicolumn{2}{|c|}{$56.76 \pm 0.22^{\mathrm{NS}}$} & $6.43 \pm 0.02^{\mathrm{NS}}$ \\
\hline \multicolumn{2}{|c|}{ Morning $\left(12^{\circ} \mathrm{C}\right)$} & \multicolumn{2}{|c|}{$56.43 \pm 0.21^{\mathrm{B}}$} & $6.44 \pm 0.02^{\mathrm{NS}}$ \\
\hline \multicolumn{2}{|c|}{ Time Afternoon $\left(20^{\circ} \mathrm{C}\right)$} & \multicolumn{2}{|c|}{$56.70 \pm 0.21^{\mathrm{AB}}$} & $6.41 \pm 0.02^{\mathrm{NS}}$ \\
\hline \multicolumn{2}{|c|}{ Early evening $\left(24^{\circ} \mathrm{C}\right)$} & \multicolumn{2}{|c|}{$57.40 \pm 0.26^{\mathrm{A}}$} & $6.45 \pm 0.02^{\mathrm{NS}}$ \\
\hline \multirow{2}{*}{$\begin{array}{c}\text { Hours after } \\
\text { slaughter }\end{array}$} & \multicolumn{4}{|c|}{ Period of anoxia (min) } \\
\hline & \multicolumn{2}{|c|}{$\begin{array}{c}\mathrm{pH} \text { at } 0 \mathrm{~min} \\
\text { (control) }\end{array}$} & $\mathrm{pH} \mathrm{a}$ & $\mathrm{pH}$ at $6 \mathrm{~min}$ \\
\hline 0 & \multicolumn{2}{|c|}{$6.59 \pm 0.11^{\mathrm{A}}$} & $6.56 \pm$ & $6.54 \pm 0.15^{\mathrm{A}}$ \\
\hline 1 & \multicolumn{2}{|c|}{$6.54 \pm 0.09^{\mathrm{AB}}$} & $6.52 \pm$ & $6.49 \pm 0.13^{\mathrm{AB}}$ \\
\hline 2 & \multicolumn{2}{|c|}{$6.46 \pm 0.12^{\mathrm{BC}}$} & $6.45 \pm$ & $6.45 \pm 0.12^{\mathrm{AB}}$ \\
\hline 3 & \multicolumn{2}{|c|}{$6.43 \pm 0.11^{\mathrm{CD}}$} & $6.44 \pm$ & $6.40 \pm 0.13^{\mathrm{BC}}$ \\
\hline 4 & \multicolumn{2}{|c|}{$6.37 \pm 0.08^{\mathrm{D}}$} & $6.36 \pm$ & $6.37 \pm 0.12^{\mathrm{CD}}$ \\
\hline 24 & \multicolumn{2}{|c|}{$6.26 \pm 0.07^{\mathrm{E}}$} & $6.27 \pm$ & $6.27 \pm 0.11^{\mathrm{D}}$ \\
\hline
\end{tabular}

NS = not significant; means followed by different letters in the same column indicate significant differences by Tukey's test $(\mathrm{p}<0.05)$.

Table 3. Mean \pm standard error of the length of Nile tilapia sarcomeres subjected to different periods of anoxia and slaughtered at different times of the day.

\begin{tabular}{cclc}
\hline $\begin{array}{c}\text { Period of anoxia } \\
(\mathrm{min})\end{array}$ & $(\mu \mathrm{m})$ & \multicolumn{1}{c}{ Period } & $(\mu \mathrm{m})$ \\
\hline 0 & $1.69 \pm 0.01^{\mathrm{B}}$ & Morning $\left(12^{\circ} \mathrm{C}\right)$ & $1.70 \pm 0.01^{\mathrm{NS}}$ \\
3 & $1.72 \pm 0.01^{\mathrm{A}}$ & Afternoon $\left(20^{\circ} \mathrm{C}\right)$ & $1.71 \pm 0.01^{\mathrm{NS}}$ \\
6 & $1.73 \pm 0.01^{\mathrm{A}}$ & Early evening $\left(24^{\circ} \mathrm{C}\right)$ & $1.73 \pm 0.01^{\mathrm{NS}}$ \\
\hline
\end{tabular}

NS = not significant; means in the same column followed by different letters indicate significant differences by Tukey's test $(\mathrm{p}<0.05)$. the fillet sarcomere length $(p>0.05)$. Moreover, there was no significant difference in environmental temperatures on the day of collection.

The analysis of the histological sections of tilapia fillets indicated no significant changes in the morphology of skeletal muscle fibres, considering the studied periods of permanence in anoxia. The transverse bands were perfectly visible in all histological sections, with an alternation between bands A (dark) and I (light) (Figure 1). The sarcomere length with control treatment (0 min of anoxia) (Figure 1A) was shorter $(1.69 \mu \mathrm{m})$ than that at treatments for $3 \mathrm{~min}$ (Figure $1 \mathrm{~B}$ ) and 6 min (Figure 1C).

\subsection{Expression of RyR1 and RyR3 genes and HSP70}

The period of anoxia-induced stress, time of the day and environmental temperature did not significantly affect $(p>0.05)$ the mRNA expression of the RyR1 and RyR3 genes (Table 4).

For the mRNA expression of HSP70 (Table 5), there was association $(p<0.05)$ between the period of anoxia and the time of the day. In the morning, the mRNA expression of HSP70 was lower $(\mathrm{p}<0.06)$ with the control treatment $(0 \mathrm{~min}$ of anoxia) than treatment in the other periods of anoxia. However, in the afternoon, the mRNA expression of HSP70 did not change among the different periods of anoxia.

The comparison of the mRNA expression of HSP70 among the different times of the day (morning and afternoon) indicated that with the control treatment ( 0 min of anoxia), the mRNA expression of HSP70 was lower in the morning.

Table 4. Mean \pm standard error expression of genes RyR1 and RyR3 of Nile tilapias subjected to different periods of anoxia and slaughtered at different times of the day.

\begin{tabular}{lccc}
\hline & & \multicolumn{2}{c}{ mRNA expression } \\
\cline { 3 - 4 } & & RyR1 & RyR3 \\
\hline $\begin{array}{l}\text { Period of anoxia } \\
\text { (min) }\end{array}$ & 0 & $15.08 \pm 0.56^{\mathrm{NS}}$ & $11.42 \pm 0.43^{\mathrm{NS}}$ \\
& 3 & $14.41 \pm 0.56^{\mathrm{NS}}$ & $11.28 \pm 0.48^{\mathrm{NS}}$ \\
\multirow{3}{*}{ Time } & 6 & $14.86 \pm 0.63^{\mathrm{NS}}$ & $11.19 \pm 0.48^{\mathrm{NS}}$ \\
& Morning $\left(12^{\circ} \mathrm{C}\right)$ & $14.74 \pm 0.49^{\mathrm{NS}}$ & $11.15 \pm 0.40^{\mathrm{NS}}$ \\
& Afternoon $\left(20^{\circ} \mathrm{C}\right)$ & $14.83 \pm 0.46^{\mathrm{NS}}$ & $11.44 \pm 0.45^{\mathrm{NS}}$ \\
\hline
\end{tabular}

NS $=$ not significant

Table 5. Mean \pm standard error mRNA expression of HSP70 of Nile tilapias subjected to different periods of anoxia and slaughtered at different times of the day.

\begin{tabular}{lrrr}
\hline \multirow{2}{*}{ Time of the day } & \multicolumn{3}{c}{ Period of anoxia (min) } \\
\cline { 2 - 4 } & 0 & 3 & 6 \\
\hline Morning $\left(12^{\circ} \mathrm{C}\right)$ & $7.07 \pm 1.33^{\mathrm{Ab}}$ & $11.04 \pm 1.09^{\mathrm{Ba}}$ & $11.10 \pm 1.09^{\mathrm{Ba}}$ \\
Afternoon $\left(20^{\circ} \mathrm{C}\right)$ & $11.18 \pm 1.33^{\mathrm{Aa}}$ & $8.09 \pm 1.33^{\mathrm{Aa}}$ & $8.07 \pm 1.09^{\mathrm{Aa}}$ \\
\hline Different uppercase letters in each line indicate significant differences $(\mathrm{p}<0.05)$, and \\
different lowercase letters between columns indicate significant differences $(\mathrm{p}<0.06)$.
\end{tabular}




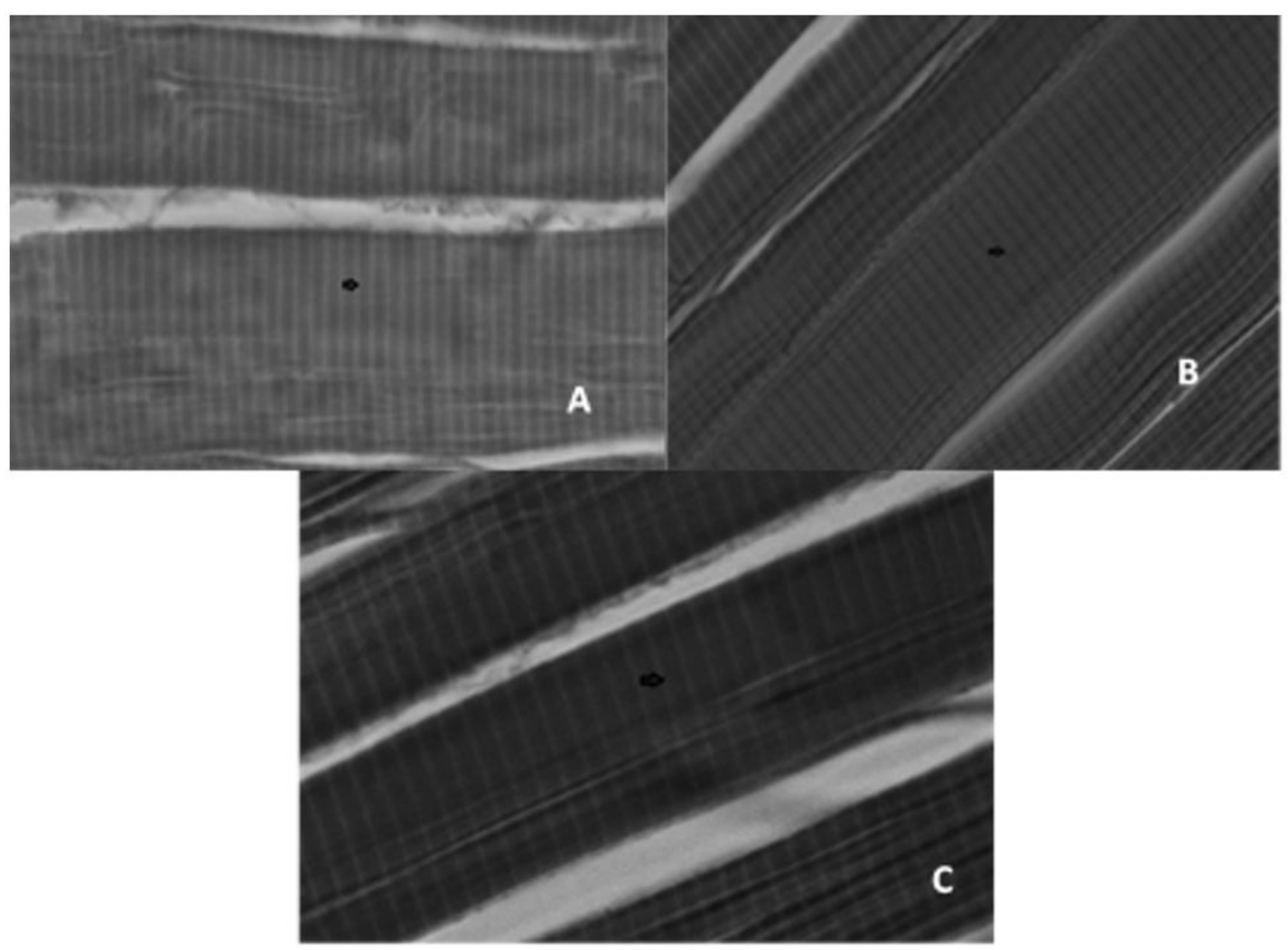

Figure 1. Representative photomicrographs of the muscle fibres of the white muscles of Nile tilapias. (A) Zero minutes of anoxia in the preslaughter period, (B) 3 min of anoxia in the pre-slaughter period and (C) 6 min of anoxia in the pre-slaughter period.

\section{Discussion}

Cortisol and blood glucose levels are usually analysed to assess stress in fishes. Fishes respond to stressors by releasing hormones (such as cortisol), which increases glucose production (Wu et al., 2016). In the present study, the exposure of tilapias to anoxia for 3 and $6 \mathrm{~min}$ increased the serum cortisol levels compared with fishes removed from the net-tank and immediately slaughtered. Plasma glucose levels significantly increased only in the fishes subjected to $6 \mathrm{~min}$ of anoxia. Considering that the change in the blood cortisol level is considered a primary response of the body to stress (Ellis et al., 2012), our results demonstrate that anoxia, regardless of the duration, can cause stress in fishes, as reported by O'Connor et al. (2011) Because cortisol levels in fishes exposed to anoxia for 3 and 6 min were statistically similar, the animals may have reached borderline cortisol levels at $3 \mathrm{~min}$ of anoxia.

Cortisol activates the central nervous system by increasing the glucose level via different metabolic pathways, including the breakdown of hepatic or muscle glycogen stores and increase in protein metabolism (Mommsen et al., 1999). The analysis of blood glucose and cortisol levels in the present study indicated that exposure to anoxia was stressful to tilapias to the point of causing changes in their physiological status.

The evaluation of slaughter at different times of the day (morning, afternoon and early evening) indicated that slaughter in the morning increased the plasma glucose level, regardless of the period of anoxia. However, serum cortisol levels did not differ among the different times of the day. Considering that a lower atmospheric temperature occurred in the morning $\left(12{ }^{\circ} \mathrm{C}\right)$, the high glucose level in the animals slaughtered in the morning suggests that colder temperature acts as a stress factor before slaughter. As glucose is an important energetic substrate for various tissues, increased glucose production may help the animal to metabolically cope with the increased energy demand caused by stress (Wu et al., 2016).

Pre-slaughter stress in fish may lead to undesirable characteristics such as extreme flaccidity, increased gapping incidence, decreased WHC and increased muscle activity by reducing energy reserves and affecting the development of rigor mortis (Roth et al., 2002; Lambooij et al., 2006; Bagni et al., 2007). In addition, ante-mortem stress may affect the level of glycogen storage and consequently, post-mortem $\mathrm{pH}$ (Gatica et al., 2010; Intarak et al., 2015). The reduction in $\mathrm{pH}$ due to lactic acid accumulation is one of the most significant post-mortem changes in muscles.

However, in the present study, no changes were observed in the $\mathrm{pH}$ of fillets of tilapia slaughtered at 0,3 or $6 \mathrm{~min}$ of anoxia, and the time of the day did not affect the final $\mathrm{pH}$ of the meat. These results may be because fish muscle contains a relatively lower glycogen level than mammals and less lactic acid is generated after death. However, several authors have reported a lower $\mathrm{pH}$ in the meat of pre-slaughtered fish such as salmon (Einen et al., 
2002), eel (Marx et al., 1997; Morzel \& Van De Vis, 2003) and snapper (Sparus aurata) (Matos et al., 2010).

The decrease in $\mathrm{pH}$ at the time of death is rapid and depends on the conditions of capture, among other factors, because the use of glycogen reserves depends on the resistance of fish to capture (Kai \& Morais, 1998). This rate of $\mathrm{pH}$ decrease and its final value reflect the characteristics of glycolysis, which affect meat quality, and indicate normal behaviour during rigor mortis.

In the present study, the sarcomere length of fish with higher serum cortisol levels (subjected to anoxia for 3 and $6 \mathrm{~min}$ ) was higher. In muscle fibre, sarcomeres are bounded by two successive Z-lines, where fine filaments are anchored and thick filaments are located in the middle (Sabow et al., 2015). Sarcomere length is related to meat tenderness as muscles with longer sarcomeres are less resistant to shear force (these meat products are softer) (Weaver et al., 2008) and are more susceptible to post-mortem proteolysis (England et al., 2012). Therefore, it can be inferred that stress induced by anoxia for 3 and $6 \mathrm{~min}$ in Nile tilapias produces fillets with a less firm texture. Acute stress before slaughter may be related to the formation of fish meat with less firm texture. Accordingly, the meat of salmon (Salmo salar) stressed for a short time (10 min under high-density rearing conditions) had a less firm texture and a significant decrease in $\mathrm{pH}$ (Sigholt et al., 1997).

Another consequence of pre-slaughter stress appears to be the decrease in WHC of fish (Bjørnevik \& Solbakken, 2010; Digre et al., 2011; Hultmann et al., 2012; Goes et al., 2015). In the present study, WHC of fish with a lower serum cortisol level (control treatment) was not significantly different from that of animals with high cortisol levels. However, WHC evaluation at different times of the day indicated a higher WHC for animals slaughtered in the early evening, and the plasma glucose level of the fish was also lower in this period. Similarly, a previous study reported a direct relationship between a higher level of stress in fish (with higher plasma glucose levels) and lower WHC in fillets of Nile tilapia (Goes et al., 2018). The lower WHC of meat increases the release of exudate and produces drier meat with less nutritional value (Zeola et al., 2007).

The ability of muscles to retain water is affected by several factors, including $\mathrm{pH}$, oxidation of post-mortem proteins, proteolytic activity of enzymes that hydrolyse meat proteins and crosslinking of myofibril proteins (Lund et al., 2011). In addition, alterations in WHC are related to changes in the mRNA expression of the ryanodine receptor proteins RyR1 and RyR3 (Goes et al., 2015). Ryanodine receptors control the release of $\mathrm{Ca}^{2+}$ from intracellular stores. Physical stress may cause changes in the activity of ryanodine receptors and decrease their ability to control the entry of $\mathrm{Ca}^{2+}$ into the cytoplasm of muscle cells (Huff-Lonergan \& Lonergan, 2005). Excess calcium in the cytoplasm increases muscle contraction, which accelerates anaerobic metabolism and post-mortem glycolysis, which, in turn, dramatically decreases muscle $\mathrm{pH}$ and affects the ability of muscles to retain water in intracellular stores (Goes et al., 2015). RyR1 mRNA expression in Nile tilapias with lower WHC due to transport-induced stress before slaughter was lower than that in fish with higher WHC (Goes et al., 2015). However, in the present study, acute stress from exposure to anoxia did not significantly change the mRNA levels of RyR1 and RyR3.

In spite of this, the expression of HSP70 mRNA was affected by stress because the serum cortisol level in fish not subjected to anoxia (control treatment) was lower and HSP70 mRNA expression was lower in the morning. Anoxia for 3 and 6 min increased the cortisol level and HSP70 mRNA expression. This may be because HSP70 is produced by all organisms exposed to stress. HSPs are induced by many physical and chemical factors, including anoxia, ischemia, toxins, protein degradation, hypoxia, acidosis and bacterial infection (Roberts et al., 2010). Delaney \& Klesius (2004) reported significantly higher HSP70 levels in the blood, brain and muscles of Nile tilapias exposed to hypoxia, suggesting that physiological adaptations that allow the survival of Nile tilapias under stressful conditions may be accompanied by the induction of HSP70 expression. Furthermore, Lückstädt et al. (2004) and Basu et al. (2001) studied hypoxia-induced stress in tilapias and trouts and observed that the increase in circulating cortisol levels increased HSP70 expression.

\section{Conclusions}

To conclude, the period of anoxia of 3 and 6 min before the slaughter of Nile tilapias increased the blood level and expression of HSP70 mRNA, leading to the formation of meat with a less firm texture (longer sarcomere length). Regarding $\mathrm{pH}$ and WHC, the evaluated period of anoxia did not affect these parameters. The fillets of fish slaughtered in the early evening had a higher WHC and lower plasma glucose level than those slaughtered at the other time periods.

These results confirm that acute pre-slaughter stress caused by anoxia for up to 6 min does not significantly affect meat quality. However, more studies are needed to elucidate the mechanisms underlying pre-slaughter stress in tilapias.

\section{References}

Association of Official Analytical Chemists - AOAC. (1995). Official methods of analysis of AOAC international (16th ed.). Arlington: AOAC International.

Bagni, M., Civitareale, C., Priori, A., Ballerini, A., Finoia, M., Brambilla, G., \& Marino, G. (2007). Pre-slaughter crowding stress and killing procedures affecting quality and welfare in sea bass (Dicentrarchus labrax) and sea bream (Sparus aurata). Aquaculture (Amsterdam, Netherlands), 263(1-4), 52-60. http://dx.doi.org/10.1016/j. aquaculture.2006.07.049.

Basu, N., Nakano, T., Grau, E. G., \& Iwama, G. K. (2001). The effects of cortisol on heat shock protein 70 levels in two fish species. General and Comparative Endocrinology, 124(1), 97-105. http://dx.doi. org/10.1006/gcen.2001.7688. PMid:11703075.

Behmer, O. A., Tolosa, E. M. C., \& Feritas-Neto, A. G. F. (1976). Manual of techniques for normal and pathological histology. São Paulo: Editora da USP.

Bjørnevik, M., \& Solbakken, V. (2010). Pre-slaughter stress and subsequent effect on flesh quality in farmed cod. Aquaculture Research, 41, e467-e474.

Brasil, Ministério da Agricultura, Pecuária e Abastecimento, Laboratório Nacional de Referência Animal. (1981, Outubro 13). Portaria nº 001/81 - 07/10/1981. Métodos Analíticos Oficiais para Controle 
de Produto de Origem Animal e seus Ingredientes. Diário Oficial [da] República Federativa do Brasil.

Castro, P. L., Lewandowski, V., Souza, M. L. R., Coradini, M. F., Alexandre, A. A. C., Sary, C., \& Ribeiro, R. P. (2017). Effect of different periods of pre-slaughter stress on the quality of the Nile tilapia meat. Food Science and Technology (Campinas), 37(1), 52-58. http://dx.doi. org/10.1590/1678-457x.05616.

Cheng, Q., \& Sun, D.-W. (2008). Factors affecting the water holding capacity of red meat products: a review of recent research advances. Critical Reviews in Food Science and Nutrition, 48(2), 137-159. http:// dx.doi.org/10.1080/10408390601177647. PMid:18274969.

Coble, D. J., Redmond, S. B., Hale, B., \& Lamont, S. J. (2011). Distinct lines of chickens express different splenic cytokine profiles in response to Salmonella Enteritidis challenge. Poultry Science, 90(8), 1659-1663. http://dx.doi.org/10.3382/ps.2010-01279. PMid:21753200.

Darbandi, S., \& Franck, J. P. C. A. (2009). Comparative study of ryanodine receptor (RyR) gene expression levels in a basal ray-finned fish, bichir (Polypterus ornatipinnis) and the derived euteleost zebrafish (Danio rerio). Comparative Biochemistry and Physiology. Part B, Biochemistry \& Molecular Biology, 154(4), 443-448. http://dx.doi. org/10.1016/j.cbpb.2009.09.003. PMid:19755169.

Davis, E. L., \& Schreck, C. B. (1997). The energetic response to handling stress in juvenile coho salmon. Transactions of the American Fisheries Society, 126(2), 248-258. http://dx.doi.org/10.1577/15488659(1997) 126<0248:TERTHS>2.3.CO;2.

Delaney, M. A., \& Klesius, P. H. (2004). Hypoxic conditions induce Hsp70 production in blood, brain and head kidney of juvenile Nile tilapia Oreochromis niloticus (L.). Aquaculture (Amsterdam, Netherlands), 236(1-4), 633-644. http://dx.doi.org/10.1016/j. aquaculture.2004.02.025.

Digre, H., Erikson, U., Skaret, J., Lea, P., Gallart-Jornet, L., \& Misimi, E. (2011). Biochemical, physical and sensory quality of ice-stored Atlantic cod (Gadus morhua) as affected by pre-slaughter stress, percussion stunning and AQUI-S ${ }^{\mathrm{rn}}$ anaesthesia. European Food Research and Technology, 233(3), 447-456. http://dx.doi.org/10.1007/ s00217-011-1531-8.

Einen, O., Guerin, T., Fjæra, S. O., \& Skjervold, P. O. (2002). Freezing of pre-rigor fillets of Atlantic salmon. Aquaculture (Amsterdam, Netherlands), 212(1-4), 129-140. http://dx.doi.org/10.1016/S00448486(01)00874-2.

Ellis, T., Yildiz, H. Y., López-Olmeda, J., Spedicato, M. T., Tort, L., Øverli, Ø., \& Martins, C. I. (2012). Cortisol and finfish welfare. Fish Physiology and Biochemistry, 38(1), 163-188. http://dx.doi. org/10.1007/s10695-011-9568-y. PMid:22113503.

England, E. M., Fisher, K. D., Wells, S. J., Mohrhauser, D. A., Gerrard, D. E., \& Weaver, A. D. (2012). Postmortem titin proteolysis is influenced by sarcomere length in bovine muscle. Journal of Animal Science, 90(3), 989-995. http://dx.doi.org/10.2527/jas.2011-4278. PMid:21984717.

Fabbri, E., Valbonesi, P., \& Franzellitti, S. (2008). HSP expression in bivalves. Invertebrate Survival Journal : ISJ, 5, 135-161.

Gatica, M. C., Monti, G. E., Knowles, T. G., \& Gallo, C. B. (2010). Muscle $\mathrm{pH}$, rigor mortis and blood variables in Atlantic salmon transported in two types of well-boat. The Veterinary Record, 166(2), 45-50. http://dx.doi.org/10.1136/vr.c71. PMid:20064978.

Goes, E. S. R., Lara, J. A. F., Gasparino, E., Del Vesco, A. P., Goes, M. D., Alexandre, L. Fo., \& Ribeiro, R. P. (2015). Pre-slaughter stress affects ryanodine receptor protein gene expression and the water-holding capacity in fillets of the Nile tilapia. PLoS One, 10(6), e0129145. http://dx.doi.org/10.1371/journal.pone.0129145. PMid:26053858.
Goes, E. S. D. R., Lara, J. A. F. D., Gasparino, E., Goes, M. D., Zuanazzi, J. S. G., Lopera-Barrero, N. M., Rodriguez, M. P. R., Castro, P. L., \& Ribeiro, R. P. (2018). Effects of transportation stress on quality and sensory profiles of Nile tilapia fillets. Scientia Agricola, 75(4), 321-328. http://dx.doi.org/10.1590/1678-992x-2016-0387.

Huff-Lonergan, E., \& Lonergan, S. M. (2005). Mechanisms of waterholding capacity of meat: the role of postmortem biochemical and structural changes. Meat Science, 71(1), 194-204. http://dx.doi. org/10.1016/j.meatsci.2005.04.022. PMID: 22064064.

Hultmann, L., Phu, T. M., Tobiassen, T., Aas-Hansen, Ø., \& Rustad, T. (2012). Effects of pre-slaughter stress on proteolytic enzyme activities and muscle quality of farmed Atlantic cod (Gadus morhua). Food Chemistry, 134(3), 1399-1408. http://dx.doi.org/10.1016/j. foodchem.2012.03.038. PMid:25005959.

Intarak, I., Lhasudta, P., Jathurasitha, S., Wicke, M., \& Kreuzer, M. (2015). Effects of slaughter weight on carcass and meat characteristics of Punga Fish (Pangasius bocourti Sauvage). Agriculture and Agricultural Science Procedia, 5, 164-169. http://dx.doi.org/10.1016/j. aaspro.2015.08.025.

Iwama, G. K., Afonso, L. O., Todgham, A., Ackerman, P., \& Nakano, K. (2004). Are hsps suitable for indicating stressed states in fish? The Journal of Experimental Biology, 207(Pt 1), 15-19. http://dx.doi. org/10.1242/jeb.00707. PMid:14638828.

Kai, M., \& Morais, C. (1998). Deterioration pathways of fish (Vias de deterioração do pescado). In: M. Kai \& U. E. Ruivo. Quality control of fish (Controle de qualidade do pescado; pp. 13-20). Santos: Leopoldianum.

Lambooij, B., Kloosterboer, K., Gerritzen, M. A., Andre, G., Veldman, M., \& Van De Vis, H. (2006). Electrical stunning followed by decapitation or chilling of African catfish (Clarias gariepinus): assessment of behavioral and neural parameters and product quality. Aquaculture Research, 37(1), 61-70. http://dx.doi.org/10.1111/j.13652109.2005.01395.x.

Lückstädt, C., Schill, R. O., Focken, U., Köhler, H. R., \& Becker, L. (2004). Stress protein Hsp70 response of Nile tilapia Orechromis niloticus (Linnaeus, 1758) to induced hypoxia and recovery. Verhandlungen der Gesellschaft fur Ichthyologie, 4, 137-141.

Lund, M. N., Heinonen, M., Baron, C. P., \& Estévez, M. (2011). Protein oxidation in muscle foods: a review. Molecular Nutrition \& Food Research, 55(1), 83-95. http://dx.doi.org/10.1002/mnfr.201000453. PMid:21207515.

Martins, M. L., Pilarski, F., Onaka, E. M., Nomura, D. T., Fenerick, J., Ribeiro, K., Myiazaki, D. M., Castro, M. P., \& Malheiros, E. B. (2004). Hematology and acute inflammatory response of Oreochromis niloticus (Osteichthyes: Cichlidae) subjected to single and consecutive stimuli of capture stress (Hematologia e resposta inflamatória aguda em Oreochromis niloticus (Osteichthyes: Cichlidae) submetida aos estímulos único e consecutivo de estresse de captura). Boletim do Instituto de Pesca, 30, 71-80.

Marx, H., Brunner, B., Weinzierl, W., Holfmann, R., \& Stolle, A. (1997). Methods of stunning freshwater fish: impact on meat quality and aspects of animal welfare. Verhandlungen der Gesellschaft fur Ichthyologie, 204A, 282-286.

Matos, E., Gonçalves, A., Nunes, M. L., Dinis, M. T., \& Dias, J. (2010). Effect of harvesting stress and slaughter conditions on selected flesh quality criteria of gilthead seabream (Sparus aurata). Aquaculture (Amsterdam, Netherlands), 305(1-4), 66-72. http://dx.doi.org/10.1016/j. aquaculture.2010.04.020.

Mommsen, T. P., Vijayan, M. M., \& Moon, T. W. (1999). Cortisol in teleosts: dynamics, mechanisms of action, and metabolic regulation. 
Reviews in Fish Biology and Fisheries, 9(3), 211-268. http://dx.doi. org/10.1023/A:1008924418720.

Morris, J. P., Thatje, S., \& Hauton, C. (2013). The use of stress-70 proteins in physiology: a re-appraisal. Molecular Ecology, 22(6), 1494-1502. http://dx.doi.org/10.1111/mec.12216. PMid:23599959.

Morzel, M., \& Van De Vis, H. (2003). Effects of the slaughter method on the quality of raw and smoked eels (Anguilla L.). Aquaculture Research, 34(1), 1-11. http://dx.doi.org/10.1046/j.1365-2109.2003.00754.x.

O’Connor, E. A., Pottinger, T. G., \& Sneddon, L. U. (2011). The effects of acute and chronic hypoxia on cortisol, glucose and lactate concentrations in different populations of three-spined stickleback. Fish Physiology and Biochemistry, 37(3), 461-469. http://dx.doi. org/10.1007/s10695-010-9447-y. PMid:21053067.

Roberts, R. J., Agius, C., Saliba, C., Bossier, P., \& Sung, Y. Y. (2010). Heat shock proteins (chaperones) in fish and shellfish and their potential role in relation to fish health: a review. Journal of Fish Diseases, 33(10), 789-801. http://dx.doi.org/10.1111/j.1365-2761.2010.01183.x. PMid:20678104.

Roth, B., Moeller, D., Veland, J. O., Imsland, A., \& Slinde, E. (2002). The effect of stunning methods on rigor mortis and texture properties of Atlantic salmon (Salmo Salar). Journal of Food Science, 67(4), 1462-1466. http://dx.doi.org/10.1111/j.1365-2621.2002.tb10306.x.

Sabow, A. B., Sazili, A. Q., Zulkifli, I., Goh, Y. M., Ab Kadir, M. Z., \& Adeyemi, K. D. (2015). Physico-chemical characteristics of Longissimus lumborum muscle in goats subjected to halal slaughter and anesthesia (halothane) pre-slaughter. Animal Science Journal, 86(12), 981-991. http://dx.doi.org/10.1111/asj.12385. PMid:26208249.

Sigholt, T., Erikson, U., Rustad, T., Johansen, S., Nordtvedt, T. S., \& Seland, A. (1997). Handling stress and storage temperature affect meat quality of farmed-raised Atlantic salmon (Salmo salar). Journal of Food Science, 62(4), 898-905. http://dx.doi.org/10.1111/j.1365-2621.1997. tb15482.x.

Sloss, M. W., \& Kemp, R. L. (1978). Veterinary clinical parasitology (5th ed). Iowa: Iowa State University Press.
Tornberg, E., Wahlgren, M., Brøndum, J., \& Engelsen, S. B. (2000). Prerigor conditions in beef under varying temperature and $\mathrm{pH}$ falls studied with rigormeter NMR and NIR. Food Chemistry, 69(4), 407418. http://dx.doi.org/10.1016/S0308-8146(00)00053-4.

Viegas, E. M. M., Pimenta, F. A., Previero, T. C., Gonçalves, L. U., Durães, J. P., Ribeiro, M. A. R., \& Oliveira, P. R. C. Fo. (2012). Methods of slaughtering and quality of fish meat (Métodos de abate e qualidade da carne de peixe). Archivos de Zootecnia, 61, 41-50.

Weaver, A. D., Bowker, B., \& Gerrard, D. (2008). Sarcomere length influences postmortem proteolysis of excised bovine semitendinosus muscle. Journal of Animal Science, 86(8), 1925-1932. http://dx.doi. org/10.2527/jas.2007-0741. PMid:18375664.

Wu, H., Arai, M., Ohnuki, H., Yoshiura, Y., \& Endo, H. (2016). Development of a flow injection biosensor system enables glucose and cortisol simultaneous measurement for the evaluation of fish stress. In Meeting Abstracts (no. 53, pp. 3913-3913). Pennington: The Electrochemical Society.

Wu, R., Sun, Y., Lei, L. M., \& Xie, S. T. (2008). Molecular identification and expression of heat shock cognate 70 (HSC70) in the Pacific White Shrimp Litopenaeus vannamei. Molekuliarnaia Biologiia, 42(2), 234-242. http://dx.doi.org/10.1134/S002689330802009X. PMid:18610835.

Yang, C. G., Wang, X. L., Tian, J., Liu, W., Wu, F., Jiang, M., \& Wen, H. (2013). Evaluation of reference genes for quantitative real-time RT-PCR analysis of gene expression in Nile tilapia (Oreochromis niloticus). Gene, 527(1), 183-192. http://dx.doi.org/10.1016/j. gene.2013.06.013. PMid:23792389.

Zeola, N. M. B., Souza, P. A., Souza, H. B., Silva, A. G. So., \& Barbosa, J. C. (2007). Color, water retention capacity, and softness of maturated lamb meat injected with calcium chloride (Cor, capacidade de retenção de água e maciez da carne de cordeiro maturada e injetada com cloreto de cálcio). Arquivo Brasileiro de Medicina Veterinária e Zootecnia, 59(4), 1058-1066. http://dx.doi.org/10.1590/S010209352007000400036. 